\title{
A Review on Eco-Friendly Natural Plant and Animal Products for Plant Diseases Management
}

\author{
Gowdra Nagamma ${ }^{1 *}$, G. Vijayalakshmi ${ }^{1}$, M.T. Sanjay ${ }^{3}$, C.R. Jahir Basha ${ }^{2}$, \\ N. Mallikarjuna ${ }^{2}$ and Mahin Sharif ${ }^{4}$ \\ ${ }^{1} Z B N F$ project, India \\ ${ }^{2}$ Plant Pathology ORP member ZBNF, India \\ ${ }^{3}$ Department of Agronomy principle investigators $Z B N F$ project, GOK, India \\ ${ }^{4}$ gricultural marketing, ORP member $Z B N F$ project, GOK, India
}

*Corresponding author

\section{Keywords}

Botanical, Plant extract, Plant diseases and Antimicrobial compounds

Article Info

Accepted:

15 July 2019

Available Online:

10 August 2019

\section{A B S T R A C T}

The overzealous and indiscriminate use of most of the synthetic fungicides has created different types of environmental and toxicological problems. Recently, in different parts of the world, attention has been paid towards exploitation of higher plant products as novel chemotherapeutants in plant protection. Pyrethroids, and neem products are well established commercially as botanical pesticides and recently some essential oils of higher plants and animals products have also been used as antimicrobials against diseases. In the context of agricultural disease management, botanical pesticides are best suited for use in organic food production in industrialized countries but can play a much greater role in the production and post-harvest protection of food products in developing countries. To achieve these multiple functionalities, sustainable plant disease management should place emphases on rational adaptation of resistance, avoidance, elimination and remediation strategies individually and collectively, guided by traits of specific host-pathogen associations using evolutionary ecology principles to create environmental (biotic and abiotic) conditions favourable for host growth and development while adverse to pathogen reproduction and evolution.

\section{Introduction}

India is the second most populous country in the world. With the increasing population, the cultivable land resource is shrinking day to day. To meet the food, fibre, fuel, fodder and other needs of the growing population, the productivity of agricultural land and soil health needs to be improved. Green Revolution in the post-independence era has shown path to developing countries for selfsufficiency in food but sustaining agricultural production against the finite natural resource base demands has shifted from the "resource degrading" chemical agriculture to a "resource protective" biological or sustainable 
agriculture. The overzealous and indiscriminate use of most of the synthetic fungicides has created different types of environmental and toxicological problems. Recently, in different parts of the world, attention has been paid towards exploitation of higher plant products as novel chemotherapeutants in plant protection. The popularity of botanical pesticides is once again increasing and some plant products are being used globally as green pesticides.

Chemical control of most of the diseases of plants may be available and could extensively reduce the impact of plant diseases, but field application of synthetic fungicides may not always be desirable. Increasing awareness of environmental impact of conventional high input intensive farming system has led to a move towards alternatives. Use of natural and conventional resources for the management of plant diseases is currently being advocated Furthermore, these compounds are natural in origin, have minimum adverse effects on the physiological processes of plants and are easily convertible into common eco-friendly organic materials (Gnanamanickam, 2002).

In Indian agriculture, the yield gap in various crops still remains large even after following the best management practices. Also the agricultural lands continue to shrink and there is a greater threat to global environment and soil resources in the form of erosion of biodiversity and climate change marching towards desertification and environmental pollution. Hence, there is now a great concern to maintain soil health and protect environment by popularizing eco-friendly and cost effective organics. Rapid increase in population and demand of food materials has initiated the large scale use of chemicals resulting in harmful biomagnifications and infertility of soils. Indiscriminate use of these chemicals has led to resistance, killing of beneficial microorganisms and imbalance in the ecosystem. To overcome these problems, plant and animal based substances and certain indigenous practices offer safe alternatives in disease management.

With this background a review has been made to study the effect of various plant and animal based substances and certain indigenous practices in plant disease management.

\section{Plant extracts}

Plant extracts, essential oils, gums, resins etc. have been shown to exert biological activity against plant fungal pathogens in vitro and in vivo and can be used as bio-fungicidal products (Fawzi et al., 2009; Jalili et al., 2010; Romanazzi et al., 2012). These products are generally assumed to be more acceptable and less hazardous for the ecosystems and could be used as alternative remedies for treatment of plant diseases (Chuang et al., 2007).

Natural plant products have a narrow target range with specific mode of action, therefore are suitable for a specific target, mostly nontoxic for antagonistic microorganisms, show limited field persistence and have a shorter shelf life and no residual threats. They often constitute a part of integrated pest management (IPM) programs, generally safe to humans and environment in comparison to conventional synthetic chemical pesticides. They can easily be adopted by farmers in developing countries who traditionally use plant extracts for the control of diseases (Nuzhat and Vidyasagar, 2013). Many reports approve the efficacy of natural products of plants in controlling fungal growth and mycotoxin production, e.g. cinnamon, clove, oregano, palmarosa and lemongrass oils (Marin et al., 2004), tea tree oil (Burgiel and Smaglowski, 2008), common thyme, cinnamon leaf and aniseed oils (Cosic et al., 2010), sweetbasil, neem, eucalyptus, datura, garlic and oleander extracts (Nashwa and 
Abo-Elyousr, 2012) (Table 1). Thymol and carvacrol are definitely the most effective active constituents against most fungal species tested (Numpaque et al., 2011; Shin et al., 2014; Villanueva Bermejo et al., 2015; Gavaric et al., 2015). The mechanism of action of these compounds against fungi is not completely understood but it is supposed to be in relation to their general ability to dissolve or otherwise disrupt the integrity of fungal cell walls and cell membranes (Isman and Machial, 2006). Some more examples regarding antifungal potential of plant products are listed in table 2. Chemical composition and mode of action of plant products the most commonly plant products used for plant disease management are essential oils and extracts. These two types of plant based products have many similarities but also differ for some characteristics. Essential oils are oily liquids obtained from plants through fermentation and steam distillation (Burt, 2004), whereas plant extracts, in contrast are obtained from dried plant products by filtration and evaporation using various solvents (Wang et al., 2004). The major compounds that have been investigated to date include phenols, flavonoids, quinones, terpenens, tannins, alkaloids, lectins, polypeptides, saponins and sterols (Halama and Van Haluwin, 2004). These products may have fungicidal or fungistatic activity on plant pathogens or they can create conditions unfavourable for establishment and multiplication of pathogenic microorganisms on host plants (Scheuerell and Mahaffee, 2002). Simple phenols and phenolic acids are bioactive phyto-chemicals consisting a single substituted phenolic ring. Phenolic toxicity to microorganisms is due to the site (s) and number of hydroxyl groups present in the phenolic compound. Quinones are characteristically highly reactive, colored compounds with two ketone substitutions in aromatic ring. Flavones, flavonoids and flavonols are phenolic structures with one carbonyl group. They are synthesized by plants in response to microbial infection and are often found effective in vitro as antimicrobial substance against a wide array of microorganisms. Tannins are polymeric phenolic substances possessing the astringent property (Figure 1). These compounds are soluble in water, alcohol and acetone (Gurjar et al., 2012). The mechanisms of some important natural compounds on plant pathogenic fungi are given in table 3 .

Species of some plant families such as Solanaceae for their high alkaloid contents, Mimosaceae for their high tannins contents and Lamiaceae and Meliaceae for their wide diversity of terpenoids may be more feasible for investigations regarding their biofungicidal compounds. For production of active ingredients, there are some factors that determine variability in quality and quantity of metabolites. The concentration of a chemical in different parts of a plant such as roots, leaves, flowers and fruits may differ. It may even be absent in one or more parts, therefore it is convenient to collect integral samples (Montes-Belmont and Carvajal, 1998).

Some plant contains components that are toxic to pathogens. When extracted from the plant and applied on infested crops, these components are called botanicals. Commonly used botanicals: Plant extracts: Neem (Azadirachta indica, A. Juss), Garlic (Allium sativum,Linn., Eucalyptus (Eucalyptus globulus, Labill., Turmeric (Curcuma Longa, Linn., Tobacco (Nicotiana tabacum, Linn., Ginger (Zingiber officinale, Rosc. Essential oils: Nettle oil (Urtica spp.), Thyme oil (Thymus vulgaris, Linn.), Eucalyptus oil Eucalyptus globulus, Labill. Rue oil (Ruta graveolens, Linn.), Lemon grass oil (Cymbopogon flexuosus (Steud.) Wats. and Tea tree oil (Melaleuca alternifolia). Gel and latex: Aloe vera (Tourn. Ex Linn.) (Gurjar et al., 2012). 


\section{Why consider botanicals?}

Sustainable solutions in agriculture

Reduce crop losses

Cheaper and

Eco-friendly

Organic farming and

Easily bio-degradable

Integrated Diseases Management.

Plant extracts have assumed special significance in the present day strategy of developing ecologically safe method of plant disease management (Ranjana Sarma et al., 1999). The plants and their constituents are less phytotoxic, more systemic, easily bio degradable and induced host metabolism (Malik, 1987; Gupta, 1997) to resist pathogen infection.

Antimicrobial activity of plant extracts have also been reported by many workers (Pandey and Pant, 1997). Among the higher plants, medicinal plants and their products (Gohil and Vala, 1996) have been shown to possess good efficacy against fungi, bacteria and viruses (Ushiki et al., 1996; Hussain et al., 2000; Parveen and Kumar, 2000). The root extracts of medicinal plants like Gerannium pretense L., Eupatorium fortunei L. and Sanguisorba officinalis L. were affective against $P$. aphanidermatum, $R$. solani, Verticillium dahliae and Fusarium oxysporum (Ushiki et al., 1996). Parveen and Kumar (2000) reported that the extracts from Azadirachta indica A. Juss, Polyalthia longifolia Benth and Hook, F. Ocimum tenuiflorum Benth and Hook, Catharanthus roseus L., and rhizome of Zingiber officinale L. inhibited Alternaria triticina. Antifungal activity of some of the plants is presented in table 4 .

Tewari and Mandakini (1991) reported that, leaf extracts of four plant species, Piper betel, Ocimum sanctum, Nyctanthesarbor-tristis and Citrus limon were effective in reducing the radial growth of Pyricularia oryzae, Cochliobolus miyabeanus and Rhizoctonia solani. Piper betel was found to be the best, followed by $O$. sanctum, in reducing the growth of the pathogens completely under in vitro and in checking the spread of blast, brown spot and sheath blight diseases of rice under in vivo.

Ansari (1995) tested antifungal activity of Trachispermum ammi, Cymbopogan citrates, Ocimum spp., Mentha spp., Rauwolfia spp., Lawsonia inermis and Vitex trifolia, against Rhizoctonia solani and found T. Ammi (seed), and Ocimum spp. (leaves) extracts were fungicidal whereas the other extracts had fungistatic activity. Spray of T. ammi and Ocimum spp. Extracts at 1:20 dilutions reduced the disease by 72.25 and 69.58 per cent respectively.

Tewari (1995) reported that leaf extract of Ocimum sanctum significantly inhibited both conidial germination and mycelial growth of Pyricularia oryzae in vitro and also observed that the effect of leaf extract was comparable to that of ediphenphos and carbendazim in controlling the blast disease.

The plant extracts (10\%) prepared from Acacia concinna L. and Basia latifolia (Roxb.) effectively controlled A. solani (Babu et al., 2000). The extracts of all parts of Cleome isocandra $\mathrm{L}$. were reported to inhibit the mycelial growth and spore germination of $A$. solani. The extracts of Allium sativum L. bulb, Aegle marmelos L. leaf and C. roseus flower inhibited spore germination and mycelial growth of A. solani (Vijayan, 1989). Sumathi (1996) reported that the extracts of Prosopis chilensis (Molina) Stundz, Abutilon indicum Mill. Sorghum vulgare L. and Cocos nucifera L. were more effective in inhibiting the mycelial growth and spore germination of $A$. solani by 90 per cent. The rhizome extract of Curcuma longa L. and Valeriana officinalis L. 
reduced the mycelial growth of Alternaria alternata (Kazami et al., 1993).

The flower extracts of Cassia fistula L., Rhododendron arboreum J.E. Smith and Thevetia peruviana (Pers.) Merr. Inhibited the growth of $A$. solani (Sundriyal, 1991). Shivapuri et al., (1997) reported that the ethanol extract of $A$. indica, Datura stramonium L., $O$. sanctum L, $P$. longifolia and Vinca rosea G. Don. Were more fungitoxic to Alternaria brassicicola, $R$. solani, Colletotrichum capsici and $F$. oxysporum. The inhibitory effect of leaf extract of Adenocalymna alliaceum Mart., A. indica, Murraya koenigii Sperng. onA. tenuissima under in vitro as well as in field condition was observed by Singh et al., (2001). Joy et al., (2004) stated that leaf, fruit and shell extract of Anacardium occidentale L. suppressed the growth of $A$. solani, $F$. solani, Phytophthora palmivora and Sclerotium rolfsii.

Field evaluation of garlic bulb extract and neem oil cake reduced disease incidence of leaf blight in onion caused by A. alternata (Kannan and Subbaraja, 1999). Kurucheve and Padmavathi (1998) reported that soil drenching and seed treatment of 10 per cent leaf extracts of Lawsonia inermis L., Eucalyptus globulus Labill., A. indica and bulb extract of $A$. sativum reduced the per cent disease incidence of damping off in chilli. Leaf extract of Piper betle (Alice, 1984) and E. microthecia (Narayana Bhat et al., 1990) was reported to control Pythium species when applied as soil drench. The juice obtained from shade dried Eupatorium cannabinum L. exhibited 100 per cent inhibition of mycelial growth of $P$. debaryanum, $F$. oxysporum, $R$. solani and $S$. rolfsii at 1:1 dilution (Kumar and Tirpathi, 1991). Shivapuri et al., (1997) reported that ethanol extracts of 10 plant species (A. cepa, A. sativum, A. indica, $O$. sanctum, $P$. longifolia $F$., Tagetes erecta $L$.,
Vinca rosea G. Don., D. stramonium, Calotropis procera L. R.Br. and Withania somnifera L.) have showed antimicrobial properties against five pathogens ( $R$. solani, $A$. brassicicola, F. oxysporum, $C$. capsici and $S$. sclerotiorum). Meena and Muthusamy (1999) found that application of neem cake (150 $\mathrm{kg} / \mathrm{ha}$ ) in combination with palmarosa oil $(0.1 \%)$ caused 73.6 per cent reduction in sheath blight disease incidence over control. Sindhan et al., (1999) evaluated the efficacy of water extracts of $A$. indica, Mentha arvensis L., E. globules, O. sanctum, D. alba, Bougainvillae spectabilis Willd., Z. officinalis and $A$. cepa against mycelial growth of $R$. solani and $R$. bataticola at 5 per cent concentration. The methanolic extract of Agrimonia eupatoria, Hypericum scabrum, Mentha longifolia, Onobrychis tourneyfortii, Peganum harmala, Phlomis sieheana, Pimpinella anisum and Tanacetum vulgare were found to possess the antimicrobial activity against several pathogenic fungi and bacteria (Sokmen et al., 2000).

Shivapuri et al., (1997) reported that ethanol extracts of ten plant species (Allium cepaL., Datura stramonium L., Ocimum sanctum L., Polyanthea longifolia, Tegetes erecta L., Vinca rosea and Withania somnifera L.) showed fungistatic properties against five pathogens (Rhizoctonia solani, Alternaria brassicola, Fusarium oxysporum, Colletotrichum capsici and Sclerotinia sclerotianum). Concentrations of $500 \mu \mathrm{g} / \mathrm{ml}$ and $1000 \mu \mathrm{g} / \mathrm{ml}$ were tested. Higher dose of the plant extracts was more efficient.

Ranjana et al., (1999) tested fifteen common weed species found in crop fields for their efficacy in suppressing sheath blight. They found that aqueous weed extracts of bracken fern (Diplazium esculentum), goat weed (Ageratum houstonianum), sickle pod senna (Cassia tora), black night shade (Solanum nigrum), and polygonum (Polygonum 
plebium) exhibited more than 90 per cent inhibition at 20 per cent concentration.

Kamalakannan et al., (2001) studied the efficacy of different plant extracts against blast disease under pot culture conditions and reported that, pre and post inoculation spray of Prosophis julifera, Zizyphus jujuba and Azadirachta indica exhibited greater reduction in disease incidence. However, pre-inoculation spray was comparatively more effective than post inoculation spray in reducing disease incidence. Reddy et al., (2002) revealed that aspirin was highly effective $(100 \%)$ in inhibiting mycelia growth and sclerotial production of Rhizoctonia solani fallowed by extracts of Allium sativum (61.8\%). Azadirachta indica (24.9\%) and Alliumcepa (19.3\%).

Muralidharan et al., (2003) reported that among the different plant derived products most of them reduced disease incidence and also increased grain yield harvests. The degree of disease reduction and yield increase was more pronounced when these products were applied to control blast and sheath blight diseases. Biswas and Roychoudhury (2003) evaluated the relative efficacy of six botanical formulations against the development of sheath blight disease of rice and compared with the standard check fungicide (Propioconozole 25 EC). All the botanicals significantly reduced the disease severity over control. Among the botanicals, spectaf followed by neemazal and achook performed best in reducing the disease severity and also improved yield.

Systemic resistance inducing protein (CASRIP) was identified from Clerodendrum aculeatum against PRSV infection in papaya by Srivastava et al., (2006). No virus symptoms were observed up to 6 months after inoculation, following challenge inoculation with PRSV, to the CA-SRIP treated papaya plants. There was also a significant difference in the vegetative growth of the treated plants as compared to control set of plants.

The plant extracts from Plectranthus tenuiflorus, Azadirachta indica, Clerodendrum inerme, Schinus terebinthifolius and Mirabilis jalapa as antiviral materials were evaluated against Bean common mosaic virus (BCMV) in bean plants (Elsharkawy and El-Sawy, 2015). All the tested plant extracts were effective in reducing the number of local lesions formed by BCMV. The mixing of $P$. tenuiflorus extracts with BCMV inoculum achieved the highest reduction in BCMV infection (92\%), while the mixing of S. terebinthifolius extracts with BCMV inoculum recorded the lowest reduction in BCMV infection (68\%).

\section{Medicinal plant extracts}

Plant extracts used to control of the phytopathogens have been obtained mainly from tree species such as eucalyptus and neem (24\% of the studies with extracts) and herbaceous species like garlic, citronella, mint, rue, yarrow, ginger, basil, camphor, turmeric and ocimum (54\%). Besides these there are other 237 plants from the Brazilian flora whose antimicrobial potential was tested by Brazilian researchers. With respect to groups of pathogens, the majority of the work is with those that cause disease in the plant canopy (30\% of the works with extracts), like the genus Alternaria, Bipolaris, Crinipellis, Corynespora and Colletotrichum, which respond alone for $15 \%$ of the works. The soilborne pathogens represent $20 \%$ of the researches, especially Rhizoctonia, Sclerotium, Sclerotinia, Fusarium and Phytophthora. Postharvest pathogens like Penicillium, Aspergillus and Rhizopus are in 9\% of the works and Meloidogyne nematode in $9.5 \%$. For the host plants, $30 \%$ of the work are with crops like beans, soybeans, coffee, wheat, 
cotton and cassava $20 \%$ with vegetables like cucumber and tomato, this later representing alone $15 \%$ of all the researches with extract; and $10 \%$ with the fruits like papaya, strawberry and cocoa. Details about these data can be found in the review of Stangarlin and colleagues (1994). From these presented numbers we can have an overview of the researches on alternative control of disease in plants in Brazil using natural extracts. Besides that, other researches have been made to identify plants whose extracts have compounds with biological action against phytopathogens or that induce plant resistance.

To evaluate the post-harvest control of anthracnose in banana, an in vitro assay was conducted to measure the mycelial growth of Colletotrichum musae in solid and liquid media containing 1, 5, 10, 15, 20 and $25 \%$ of camphor (fresh weigh/volume). To in vivo assay was evaluated the post-harvest control by immersing banana fruits for $3 \mathrm{~min}$ in the camphor extracts, using as control treatments Benomyl (0.25 g/L) and distillated water. The results showed that camphor inhibited $41 \%$ the mycelial growth and $86 \%$ the sporulation, in solid medium, although had stimulated the mycelial growth in liquid medium. The severity of Anthracnosewas reduced to $67 \%$ and $56 \%$ for camphor and fungicide treatments, respectively (Carré et al., 2007).

Aqueous extract (AE) of eucalyptus in concentrations of $0.1,1,5,10,15,20$ and $25 \%$ was used in the following experiments: induction of phytoalexins in sorghum etiolated mesocotyls and soybean cotyledons; in vitro fungitoxicity against Colletotrichum lagenarium; and local or systemic induction of resistance in cucumber plants against anthracnose. Water and acibenzolar-S-methyl were used as control treatments. The eucalyptus extract induced phytoalexin synthesis in sorghum starting from the concentration of $1 \%$. In soybean, glyceollin synthesis took place from $10 \%$ of aqueous extract. The phytoalexin synthesis in different incubation periods showed that greater inductions take place from 48 hours on. There was total inhibition in the spores germination and apressoria formation in concentrations of $20 \%$. Based on the parameter size of lesion, the aqueous extract of E. citriodora was capable to induce local resistance in cucumber plants against $C$. lagenarium (Bonaldo et al., 2004).

Aqueous extract from E. citriodora fresh leaves, in concentrations up $20 \%$, were efficient to inhibited in $100 \%$ the mycelial growth of Colletotrichum sublineolum, Phytophthora sp. and Sclerotium rolfsii, in $75 \%$ to Rhizoctonia solani and in $45 \%$ to Alternaria alternate, under in vitro assays (Bonaldo et al., 2007).

Zingiber officinale (ginger) the effect of aqueous extract of ginger was evaluated at concentrations of $1,5,10,15,20$ and $25 \%$ on Sclerotinia sclerotiorum mycelial growth and sclerodia production, in vitro. The efficiency of protection of ginger was also verified in lettuce plants growth organically and inoculated with the pathogen. Besides the disease incidence, the crop yield and the peroxidase induction were analysed in the tissue plants. Water and the resistance inductor acibenzolar-S-methyl were used as control treatments. Additionally, the elicitor ability of ginger extract in inducing accumulation of the phytoalexins 3deoxyanthocyanidin and glyceollin was evaluated in sorghum and soybean bioassays, respectively. The results showed the antimicrobial activity of ginger with mycelial growth and sclerodia production inhibition. In the lettuce crop, it was observed that the application of ginger mass on the soil near to plants basis caused a bigger activity of peroxidase enzyme and the reduction of disease incidence. The presence of elicitor 
compounds in the ginger extract was detected by the production of phytoalexins in sorghum and soybean, with dose-dependent response (Rodrigues et al., 2007).

Ocimum gratissimum (wild basil) the in vitro effect of wild basil crude extract (CE) (autoclaved or sterilized by filtration) as well as the iprodione + thiram fungicide on the mycelial growth and sporulation of Bipolaris sorokiniana was evaluated. Besides, wheat seeds naturally infected with $B$. sorokiniana were submitted to the following treatments: 1) fumigation with essential oil; 2) immersion with autoclaved $\mathrm{CE}$ and; 3) non autoclaved $\mathrm{CE}$ at different concentrations $(1,5,10,15$, 20,25 , and $50 \%$; w/v); 4) sprinkling with dry leaves of the medicinal plant and with the fungicide. The autoclaved $\mathrm{CE}$ showed, even partially, higher inhibition of mycelial growth in all the tested concentrations than $\mathrm{CE}$ sterilized by filtration. In greenhouse, the fumigated seeds (7 days) showed the same emergency speed (EV) concerning to the control (water). There were no statistics differences among the analyzed parameters (EV, emergency percent, height, dry mass, fresh mass, and transmission rate (TR)) when the treatment by immersion was compared with the no treated control. Seeds treated with the dry powder of medicinal leaves did not differ statistically from the chemical control, when the same parameters were evaluated, but presented higher TR of the pathogen. In the laboratory, seeds submitted to the fumigation process presented a higher number of health seeds than the non-treated control, while the treatments by immersion in the $\mathrm{CE}$ and sprinkling with dry leaves did not differ concerning to the same parameter (Rodrigues et al., 2006). Aqueous extracts of the leaves of Ocimum gratissimum at 10, 25, 40 and 50\% $(\mathrm{w} / \mathrm{v})$ concentrations induced the production of phytoalexins in soybean cotyledons and sorghum mesocotyls. The aqueous extracts also induced systemic resistance in cucumber against Colletotrichum lagenarium, reflected by reduction in disease incidence and an increase in chitinase production (Colpas et al., 2009). The essential oil and crude extract of wild basil, harvested in different seasons, were tested in vitro on the mycelial growth of Rhizoctonia solani, Sclerotium rolfsii, Phytophthora sp. and Alternaria alternata. To evaluate the effect of the essential oil, sterilized oil aliquots of $20 \mu \mathrm{L}, 40 \mu \mathrm{L}$ and 60 $\mu \mathrm{L}$ were distributed on the surface of potatodextroseagar (PDA). The aqueous extracts were filtrated and incorporated in PDA at $1 \%$, $5 \%, 10 \%, 15 \%, 20 \%, 25 \%$ and $50 \%$. The results showed total inhibition of mycelial growth in the different aliquots of essential oil. The extract collected from plants in autumn had better results; in this season the aqueous extract at 5\% was enough to provide inhibition of $100 \%$ on mycelial growth of A. alternata and S. rolfsii (Benini et al., 2010). Tagetes patula (marigold) Aqueous extract of flowers, leaves and roots of Tagetes patula were obtained by infusion in the proportion of 50 grams of dehydrated material in 1,000 $\mathrm{ml}$ of distilled water and tested in vitro on eggs and second-stage juveniles (J2) of Meloidogyne incognita, without dilution and diluted 1:1, 1:2, 1:3 and 1:4 (extract: water, v:v), and in plants of tomato cv. Santa Cruz Kadá cultivated in pots, without dilution and diluted $1: 1$. For in vivo assays, the extract was sprayed on the leaves, soil or both by four ways: weekly during eight weeks; at the transplanting (one week before inoculation); and together or one week after inoculation. The extract of flowers, leaves and roots inhibited the hatching, the mobility, and caused mortality of $\mathrm{J} 2$ in vitro.

Greater nematicide effect was obtained with roots extract, which promoted mortality up to $68 \%$ of J2. In tomato plants, results were not satisfactory with only one application of Tagetes extract. Weekly applications promoted plant development and decreased 
galling and the nematode population. Greater effect was obtained by flower extract application, followed by leaves extract. Slight or non-effect was observed by root aqueous extract. Flower extract without dilution inhibited galling up to $62.2 \%$ and decreased 61.5 and $52.8 \%$ the number of $\mathrm{J} 2$ in the soil and eggs in the roots, respectively. Applications on the soil or leaves presented similar results. These results demonstrated the potential of $T$. patula extract, mainly of flowers, to protect tomato plants against $M$. incognita. Furthermore, it was hypothesized that induced resistance was involved in the responses observed (Franzener et al., 2007).

In Kharif season Sphaerotheca fuliginea wasdominantly present on Cucurbita maxima, Lageneria siceraria and Cucurbita pepo, where as Erysiphe cichoracearum noted on Citrullus lanatus was not reported in 2005 and 2006.Cucurbita maxima, Lageneria siceraria, Luffa acutangula and Luffa cylindrica showed maximum occurrence of Sphaerotheca fuliginea in the rabbi season. Incidence of powdery mildew is more at post flowering and fruiting stage.

However powdery mildew also reported at seedling stage of Cucurbita pepo and Cucurbita maxima. Neem leaf extract at $15 \%$ concentration, Parthenium leaf at $10 \%$ concentrations. Ocimum leaf at $20 \%$ concentration, Citrus leaf at $20 \%$ concentration, Annona squamosa leaf at $10 \%$ concentration, Ipomea at $15 \%$ and Jowar leaf at $20 \%$ control the powdery mildew of cucurbits (Vasant and Ashok, 2010). Cow urine at $15 \%$ concentration proved to be effective to control powdery mildew on cucurbit. $20 \%$ to $25 \%$ of Butter milk spray successfully controlled the powdery mildew of cucurbit. Similarly $20 \%$ ash spray also found to be successful to control the growth of powdery mildew of cucurbits. Spray of Dashparni ark, a bi-product of plant and animal at $10 \%$ concentration inhibited the growth of Erysiphe cichoracearum and Sphaerotheca fuliginea

\section{Current aspects of commercially available natural products}

Although considerable research efforts throughout the world have been conducted and an ever-increasing volume of scientific literature on the pesticides properties of plant products and their constituents are available, but some pest control products based on plant essential oils/extracts have been appearing in the market which seems not enough for substituting with current synthetic pesticides. In the United States, commercial development of insecticides based on plant essential oils/extracts has been greatly facilitated by exemption from registration for certain oils commonly used in processed foods (Quarles, 1996). This opportunity has encouraged the development of some essential oil-based pesticides using rosemary oil, clove oil, and thyme oil as active ingredients for agricultural and industrial applications. Application of these products has been interesting, particularly for control of greenhouse pests and diseases. The natural plant product Milsana $®$, extracted from the giant knotweed (Reynoutria sacchalinensis) is probably the best known natural fungicide. This product has been reported to control powdery mildew, caused by Sphaerotheca fuliginea, in the long Englishcucumber under greenhouse conditions, and also showed broad spectrum activity against powdery mildew of tomato, apple and begonia as well as downy mildew of grapevine and rust of bean (Daayf et al., 1995). A product based on rosemary oil is available fungicide sold under the trade name 'Sporan TM '. A volatile natural product, Carvone $^{\mathrm{TM}}$, derived from dill and caraway seed, has been developed to inhibit the growth of storage pathogens (Moezelaar et al., 1999). 
Table.1 Botanicals

\begin{tabular}{|c|c|c|c|c|}
\hline Plant & Part used & Preparations & Diseases/pathogen & References \\
\hline $\begin{array}{l}\text { Datura/thorn apple (D.stamonium) } \\
\text { Calotropis procera (Ait.) R. Br. Oscimum } \\
\text { spp. }\end{array}$ & $\begin{array}{l}\text { Root, stem, } \\
\text { Leaf, flowers }\end{array}$ & Crude extract & Curvularia lunata & $\begin{array}{l}\text { Manoharachary and } \\
\text { Gourinath (1988) }\end{array}$ \\
\hline $\begin{array}{l}\text { Turmeric (Curcuma longa Linn.), Ginger } \\
\text { (Zingiber officinale Rosc.) }\end{array}$ & Rhizome & Crude extract & $\begin{array}{l}\text { Phytopthora infestans, Fusarium } \\
\text { solani, Pyricularia oryzae }\end{array}$ & Bandara et al., (1989) \\
\hline $\begin{array}{l}\text { Neem/Margosa (Azadirachta indica A.Juss.), } \\
\text { Sugar apple (Annona squamosa Linn.), Holy } \\
\text { basil (Oscimum sanctumLinn.) }\end{array}$ & $\begin{array}{l}\text { Leaf, Stem, } \\
\text { Bark, root }\end{array}$ & Crude extract & Anthracnose of pepper & Nduagu et al., (2008) \\
\hline Neem/Margosa (Azadirachta indica A.Juss.), & Seed kernel & Oil & A. alternata & $\begin{array}{l}\text { Dharam and Sharma } \\
\text { (1985) }\end{array}$ \\
\hline Ambrosioides Linn., Oscimum spp. & Leaf & Essential oils & Aspergillus flavus & Mishra et al., (1989) \\
\hline $\begin{array}{l}\text { Garlic (Allium sativum Linn.), Datura (D. } \\
\text { stramonium Linn.) }\end{array}$ & Bulb, Leaf & Ethanol extracts & Curvularia lunata & $\begin{array}{l}\text { Upadhyaya and Gupta } \\
(1990)\end{array}$ \\
\hline $\begin{array}{l}\text { Spearmint (Mentha spicata Linn.), Greek } \\
\text { Sage (Salvia fruticosa Mill.), Thymbra spp. }\end{array}$ & Leaf & Essential oils & $\begin{array}{l}\text { Rhizoctonia solani, Sclerotium } \\
\text { sclerotiorum }\end{array}$ & Yegen et al., (1992) \\
\hline Neem/Margosa (Azadirachta indica A.Juss.), & Seed, Leaf & Crude Extracts & Early blight of tomato & Patil et al., (2001) \\
\hline Madar (Calotropis procera (Ait.) R.Br. & Leaf & Crude Extracts & Tikka leaf spot disease of groundnut & Srinivas et al., (1997) \\
\hline Neem/Margosa (Azadirachta indica A.Juss.), & Seed & NSKE & Powdery mildew of pea & Surwase et al., (2009) \\
\hline Neem/Margosa (Azadirachta indica A.Juss.), & Leaf & $\begin{array}{l}\text { Achook formulations } \\
\text { (azadirachtina) }\end{array}$ & Sheath blight of rice & Kandhari et al., (2007) \\
\hline Neem/Margosa (Azadirachta indica A.Juss.), & Seed kernel & Neem oil & Rice tungro virus & $\begin{array}{l}\text { Muthamilan and } \\
\text { Revathy (2007) }\end{array}$ \\
\hline Neem/Margosa (Azadirachta indica A.Juss.), & Leaf, Seed & Achook, Neemazal, & Bacterial blight of rice & Sunder et al., (2005) \\
\hline $\begin{array}{l}\text { Black pepper (Piper nigrum Linn., Clove } \\
\text { (Syzygium aromaticum(Linn.) Merr. \& } \\
\text { Perry, Geranium (Pelargonium graveolens } \\
\text { L'Herit), Nutmeg (Myristica fragrans } \\
\text { Houtt.), (Origanum vulgare spp. hirtum } \\
\text { (Link) Letsw. and thyme [Thymus vulgaris } \\
\text { Linn. }\end{array}$ & Leaf & Volatile oil & $\begin{array}{l}\text { Anti bacterial (gram positive and } \\
\text { gram negative) }\end{array}$ & Dorman et al., (2000) \\
\hline
\end{tabular}


Table.2 Botanicals produced by plants having antimicrobial activity

\begin{tabular}{|c|c|c|c|c|}
\hline Common name & Scientific name & Compound & Class & Activity \\
\hline Apple & Malus pumila Mill. & Phloretin & $\begin{array}{l}\text { Flavonoid } \\
\text { derivative }\end{array}$ & General \\
\hline Aswagandgha & $\begin{array}{l}\text { Withania somnifera } \\
\text { Dunal. }\end{array}$ & Withafarin A & Lactone & Bacteria, fungi \\
\hline Bael tree & $\begin{array}{l}\text { Aegle marmelos } \\
\text { Linn. }\end{array}$ & Essential oil & Terpenoid & Fungi \\
\hline Blue germ tree & $\begin{array}{l}\text { Eucalyptus globulus } \\
\text { Labill. }\end{array}$ & Tannin & Polyphenol & $\begin{array}{l}\text { Fungi, Bacteria, } \\
\text { Viruses }\end{array}$ \\
\hline Onion & Allium cepa Linn. & Allicin & Sulfoxide & Fungi, Bacteria \\
\hline Thyme & $\begin{array}{l}\text { Thymus vulgaris } \\
\text { Linn }\end{array}$ & Caffeic acid & Terpenoid & $\begin{array}{l}\text { Fungi, Bacteria, } \\
\text { viruses }\end{array}$ \\
\hline Turmeric & Curcuma longa Linn. & Curcumin & Terpenoids & $\begin{array}{l}\text { Fungi, Bacteria, } \\
\text { protozoa }\end{array}$ \\
\hline Thome apple & $\begin{array}{l}\text { Datura stramonium } \\
\text { Linn. }\end{array}$ & Hyoscymine & Scopolamine & Alkaloids Fungi \\
\hline Black pepper & Piper nigrum Linn. & Piperine & Alkaloid & Fungi \\
\hline Castor & $\begin{array}{l}\text { Ricinus communis } \\
\text { Linn. }\end{array}$ & $\begin{array}{l}\text { Ricinine, } \\
\text { Ricininoleic }\end{array}$ & Alkaloids & Fungi \\
\hline $\begin{array}{l}\text { Neem/ Margosa } \\
\text { tree }\end{array}$ & $\begin{array}{l}\text { Azadirachta indica } \\
\text { A.Juss. }\end{array}$ & Azadirachtin & Terpenoides & Fungi, Bacteria \\
\hline Garlic & Allium sativum Linn. & Allicin & Solfoxide & Fungi, Bacteria \\
\hline
\end{tabular}

Table.3 Mechanisms of action of phytochemicals (Cowan, 1999)

\begin{tabular}{|l|l|}
\hline \multicolumn{1}{|c|}{ Name of compound } & \multicolumn{2}{c|}{ Mode of action } \\
\hline Simple Phenols & Membrane disruption, substrate deprivation \\
\hline Phenolic acids & Bind to adhesins, complex with cell wall, inactivate enzymes \\
\hline Terpenoids & Membrane disruption \\
\hline Essential oils & Membrane disruption \\
\hline Alkaloids & Intercalate into cell wall \\
\hline Tannins & Bind to proteins, enzyme inhibition, substrate deprivation \\
\hline Flavonoids & Bind to adhesins, complex with cell wall, Inactivate enzymes \\
\hline Coumarins & Interaction with eukaryotic DNA \\
\hline Lectins & Form disulfide bridges \\
\hline Polypeptides & Form disulfide bridges \\
\hline
\end{tabular}


Table.4 Fungicidal properties of some of plant products

\begin{tabular}{|c|c|c|}
\hline Name of plant product/compound & Controlled plant pathogen & Reference \\
\hline $\begin{array}{l}\text { Acacia, sapodilla, datura, eucalyptus, } \\
\text { pomegranate and black plum extracts }\end{array}$ & $\begin{array}{l}\text { Aspergillus candidus, A. flavus, A. fumigatus, A. niger, A. } \\
\text { ochraceus }\end{array}$ & Satish et al., (2007) \\
\hline Eucalyptus and lavender extracts & Alternaria alternate & $\begin{array}{l}\text { Zaker and Mosallanejad } \\
(2010)\end{array}$ \\
\hline $\begin{array}{l}\text { Clove bud, cinnamon, ginger, black pepper, } \\
\text { garlic and onion extracts }\end{array}$ & Aspergillus niger & Avasthi et al., (2010) \\
\hline Neem, chinaberry, garlic and turmeric extracts & Fusarium oxysporum, Rhizoctonia solani & Hadian (2012) \\
\hline Artemisia, thyme and eucalyptus extracts & Fusarium solani & Zaker (2014) \\
\hline $\begin{array}{l}\text { Indian beech, milk weed, oleander and turmeric } \\
\text { extracts }\end{array}$ & $\begin{array}{l}\text { Aspergillus fumigatus, Alternaria solani, Helminthosporium } \\
\text { spp }\end{array}$ & Masih et al., (2014) \\
\hline Kokum, wild turmeric and jasmine extracts & Rhizopus stolonifer, Colletotrichum coccodes & Bhagwat and Datar (2014) \\
\hline $\begin{array}{l}\text { Grape seed, thyme, rosemary, mint, basil and } \\
\text { sage essential oils }\end{array}$ & Botrytis cinerea & $\begin{array}{l}\text { Mermer-Doğu and Zobar } \\
\text { (2014) }\end{array}$ \\
\hline $\begin{array}{l}\text { Anise, cumin, caraway, ammin, pennyroyal, } \\
\text { thyme and cinnamon essential oils }\end{array}$ & $\begin{array}{l}\text { Aspergillus flavus, Phoma sorghina, Alternaria alternata, } \\
\text { Botrytis cinerea }\end{array}$ & Behdani et al., (2012) \\
\hline $\begin{array}{l}\text { Pepper and cassia extracts, neem, mustard and } \\
\text { cinnamon essential oils }\end{array}$ & Phytophthora nicotianae & Bowers and Locke (2004) \\
\hline Citral, eugenol and geraniol & Fusarium moniliforme, Curvularia lunata & $\begin{array}{l}\text { Krishna Kishore et al., } \\
(2007)\end{array}$ \\
\hline $\begin{array}{l}\text { Carvacrol, eugenol, citronellol, geraniol, citral, } \\
\text { perillyl and menthol }\end{array}$ & Monilinia fructicola, Botrytis cinerea & Tsao and Zhou (2000) \\
\hline $\begin{array}{l}\text { Thymol, carvacrol, } 1,8 \text { cineole, } Y \text {-terpinene, p- } \\
\text { cymene and anethole }\end{array}$ & $\begin{array}{l}\text { Fusarium moniliforme, Rhizoctonia solani, Phytophthora } \\
\text { capsici }\end{array}$ & $\begin{array}{l}\text { Mueller-Riebau et al., } \\
\text { (1995) }\end{array}$ \\
\hline
\end{tabular}


Fig.1 Structure of antimicrobial compounds

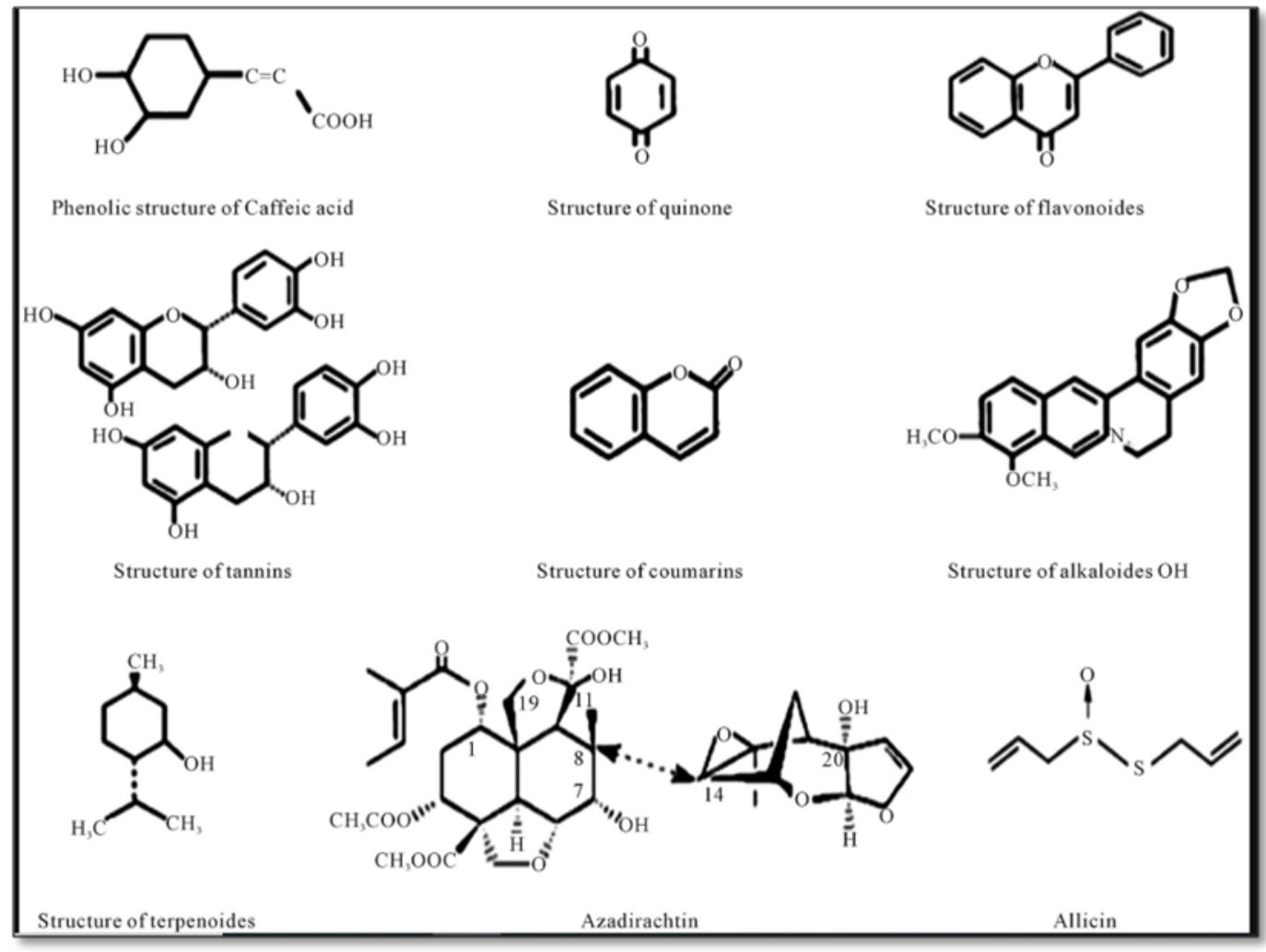

Carvone ${ }^{\mathrm{TM}}$ is currently marketed as Talent ${ }^{\circledR}$ in the Netherlands. Additionally, Fungastop ${ }^{\mathrm{TM}}$ and Armorex ${ }^{\mathrm{TM}}$ II, are two natural products developed in the USA by Soil Technologies Corp., and are commercially available for the control of various plant diseases in agriculture. TimorexGold ${ }^{\circledR}$ manufactured by Stockton group (Switzerland) is the new generation of bio-fungicides based on a plant extract of Melaleuca alternifolia for the control of powdery mildews, downy mildews, rust and early and late blight diseases in vegetables, grapevines and orchards and is harmless to beneficial insects and bees. For organic farming also some plant essential oils are marketed as fungicides. These include ERase $^{\mathrm{TM}}$ from jojoba (Simmondsia californica) oil, Sporan ${ }^{\mathrm{TM}}$ from rosemary (Rosemarinus officianalis) oil, Promax ${ }^{\mathrm{TM}}$ from thyme (Thymus vulgaris) oil, Trilogy ${ }^{\mathrm{TM}}$ from neem (Azadirakhta indica) oil and GC-3 ${ }^{\mathrm{TM}}$ being a mixture of cottonseed (Gossypium hirsutum) oil and garlic (Allium sativum) extract. Bla$\mathrm{S}^{\mathrm{TM}}$ is used against rice blast disease in eastern Asia, Kasugamin ${ }^{\mathrm{TM}}$, against rice blast and other crop diseases in Japan, Mildiomycin ${ }^{\mathrm{TM}}$, for controlling powdery mildews mainly in Japan, Delvolan ${ }^{\mathrm{TM}}$, against fungal diseases of ornamental plants and Validacin $^{\mathrm{TM}}$, for controlling Rhizoctonia root rot of a variety of crops (Dayan et al., 2009; Zaker, 2014).

\section{Animal based products}

From the ancient period in India, cow urine has been used for several medicinal purposes and the description on its use has been in several classical Ayurveda texts like Charaka samhita and Shushruta samhita. Cow is believed to be a sacred animal in India its urine is known to cure several diseases. In Veda, cow urine is compared with the nectar (Krishnamurthi et al., 2004; Gururaja et al., 
2011). Gaw-mutra (cow's urine) has been described as a liquid with innumerable therapeutic values, capable of curing several incurable diseases in human beings and plants. Cow urine is rich source of macro, micronutrients and has disinfectant and prophylactic properties. It puri- fies the atmosphere and improves the soil fertility. Cow urine has got applications in agriculture. It has been found that cow urine has potential to control Meloidogyne incognita in Lycopersicon esculentus (Abubakar et al., 2004) and aphids and pickleworms in watermelon cultivation (Burubai and Eribo, 2012). It is observed that cow urine has inhibitory effect against several plant pathogens such as Sclerotinia sclerotiorum (Basak et al., 2002a), Fusarium solani f.sp. cucurbitae (Basak et al., 2002b), Bipolaris sorokiniana (Akhter et al., 2006) and Xanthomonas oryzae $p v$. oryzae (Murugan et al., 2012). It has been shown that cow urine extract of certain plants as well as cow urine in combination with certain plant extracts are found to possess marked inhibitory effect on plant pathogens (Akhter et al., 2006; Yadav et al., 2008; Rajapandiyn et al., 2011; Tiwari \& Das, 2011)

Inhibitory efficacy of fresh and stored cow urine was tested against two phytopathogenic fungi of ginger viz., Pythium apahidermatum and Fusarium oxysporum f.sp.zingiberi isolated from soft rot specimen of ginger. Urine was collected from an indigenous cow variety 'Malnad gidda'. The effect of various concentrations of fresh and stored cow urine (3 months) viz., 5, 10, 20 and 40\% was tested against the mycelial growth of test fungi by poison food technique. The extent of growth of test fungi in poisoned plates was recorded and compared with the control. Both fresh and stored cow urine displayed concentration dependent inhibition of test fungi. Inhibitory efficacy was recorded higher for stored cow urine than fresh cow urine. The inhibition of test fungi was $>50 \%$ at $20 \%$ and higher concentrations of cow urine. $P$. aphanidermatum was inhibited to higher extent than $F$. oxysporum f. sp. zingiberi. It can be concluded that cow urine has got potential to inhibit pathogenic fungi causing rhizome rot of ginger in vitro. Field experiments are to be carried out to justify the possible utilization of cow urine against rhizome rot of ginger (Rakesh et al., 2013).

Antifungal efficacy of cow urine against Colletotrichum capsici isolated from anthracnose of chilli (Capsicum annuum L.). Poisoned food technique was employed to determine antifungal activity of different concentrations of cow urine $(5,10$ and $15 \%)$. Cow urine was found to display concentration dependent inhibitory activity against fungal growth. An inhibition of $>50 \%$ was observed at $5 \%$ concentration indicating, the use of cow urine can be the cost effective and ecofriendly approach for controlling anthracnose in chilli (Yashoda Kambar et al., 2013).

Cow urine extract, hexane, chloroform, ethyl acetate, alcohol, methanol and aqueous fractions of Pongamia pinnata Linn seed were tested against $X$. oryzaepv. oryzae for its antibacterial activity. Streptomycin sulphate $(30 \mu \mathrm{g})$ and dimethyl sulfoxide (DMSO, 15 $\mu \mathrm{L})$ are used as positive and negative control. All the extracts and fractions were effective and showed 10 to $13 \mathrm{~mm}$ zone of inhibition. Phytochemical analysis also showed the presence of terpenoids, quinine, coumarin, tannin and phenol, with flavonoid available in higher quantity (1.56 mg. $\mathrm{kg}^{-1}$ ) (Murugan et al., 2012).

Gotora et al., (2014) was carried out an in vitro assay to establish if cow urine at different concentrations $\left(500 \mu \mathrm{L} \cdot \mathrm{mL}^{-1}\right.$, $300 \mu \mathrm{L} \cdot \mathrm{mL}^{-1}, 200 \mu \mathrm{L} \cdot \mathrm{mL}^{-1}$, and $\left.100 \mu \mathrm{L} \cdot \mathrm{mL}^{-1}\right)$ can be used to control the growth of Fusarium lateritium, the fungal agent causing Fusarium 
bark disease in coffee. The growth characteristics selected were conidial germination, germ tube length, mycelial growth rate, and sporulation. Copperoxychloride $50 \%$ W.P. was the standard, distilled water was the negative control, and undiluted cow urine was the positive control. The undiluted cow urine was most effective in inhibiting fungal growth with the rest of the cow urine concentrations showing dose dependent efficacy compared to the negative control $(\mathrm{P}<0.01)$. Copperoxychloride had the highest efficacy of all treatments with the exception of the inhibition of mycelia growth where undiluted cow urine had higher efficacy and sporulation where efficacy was comparable to undiluted cow urine. There is potential for the use of cow urine as a means of controlling Fusarium bark disease with other advantages being availability, low cost and limited environmental damage.

Studies on use of jeevamrutha in management of leaf spot diseases in pomegranate were conducted in farmer's field at two locations in karnataka during 2006. The effect of jeevamrutha on groundnut registered low leaf spot incidence $(2.5 \%)$ compared to the control $(8.5 \%)$. It is attributed to the phenolic compounds and other elements present in the cow urine and dung led to the inhibition and multiplication of the pathogen and further restricts the spread of pathogen. This imparts the disease resistant once and reduced incidence (Upperi et al., 2009.).

Due to hazardous impact of most of synthetic fungicides, in the near future the use of such chemicals must be strictly regulated by governments which may lead to a growing demand for biologically plant protection materials such as plant origin products. Based on approved data and scientific publications it seems evident that plant essential oils/extracts are biodegradable and do not cause similar environmental risks like widely used synthetic chemicals. The option of replacing fossil oil based chemicals with plant product formulations fits well with food and agriculture policies directed to the future. Sustainable agriculture and food security cannot rely on the use of fossil oil as has been the case for a long time in the developing countries. Local resources should be utilized and thus production of more biopesticides should become a common practice.

\section{References}

Abubakar, U., Adamu, T. and Manga, S.B., 2004.Control of Meloidogyne incognita (kofoid and white) chitwood (root-knot nematode) of Lycopersicon esculentus (tomato) using cow dung and urine.African Journal of Biotechnology3(8): 379-381.

Akhter, N., Begum, M.F., Alam, S., Alam, M.S., 2006. Inhibitory effect of different plant extracts, cow dung and cow urine on conidial germination of Bipolaris sorokiniana. Journal of Bio-Sciences, 14: 87-92.

Alice, D. 1984. Studies on antifungal properties of some plant extracts. M.Sc. (Ag.) Thesis, Tamil Nadu Agricultural University, Coimbatore, India.156p.

Amadioha, A. C., 2000.Controlling rice blast in vivo with extract of Azadirachta indica. Crop Prot., 19(5): 287-290.

Ansari, M.M., 1995.Control of sheath blight of rice by plant extracts.Indian Phytopath.,48: 268-270.

Avasthi, S., Gautam, A. K. and Bhadauria, R. 2010. Antifungal activity of plant products against Aspergillus niger: A potential application in the control of a spoilage fungus. Biological Forum- An International Journal, 2(1): 53-55.

Babu, S., Seetharaman, K., Nandakumar, R. and Johnson, I. 2000. Fungitoxic properties of some plant extracts against Alternaria solani, the tomato leaf blight pathogen. $J$. Ecotoxicol. Envt. Monitoring, 10: 157-159.

Bandara, B.M.R., Kumar, N.S. and Samaranayake, K.M.S., 1989.An antifungal constituent from the stembark of Butea 
monosperma. Journal of Ethnopharmacology, 25: 73-75. doi:10.1016/0378-8741(89)90046-9.

Basak, A.B., Lee, M.W. and Lee, T.S., 2002b.In vitro inhibitory activity of cow urine and dung to Fusarium solani f.sp.cucurbitae. Mycobiology, 30(1):51-54.

Basak, A.B., Lee, W.M., Lee, T.S., 2002a.Inhibitive activity of cow urine and cow dung against Sclerotinia sclerotiorum of Cucumber.Mycobiology,30(3):175179.

Behdani, M., Pooyan, M. and Abbasi, S. 2012.Evaluation of antifungal activity of some medicinal plants essential oils against Botrytis cinerea, causal agent of postharvest apple rot, in vitro.International Journal of Agriculture and Crop Sciences, 4(14): 10121016.

Benini, P. C., Schwan-Estrada, K. R. F., Klais, E. C., Cruz, M. E. S., Itako, A. T., Mesquini, R. M., Stangarlin, J. R. and Tolentino Júnior, J. B., 2010.In vitro effect on phytopathogens of essential oil and aqueous crude extract of Ocimum gratissimum harvest in the four seasons.Arquivos do Instituto Biológico, 77: 677-683.

Bhagwat, M. K. and Datar, A. G. 2014. Antifungal activity of herbal extracts against plant pathogenic fungi. Archives of Phytopathology and Plant Protection, 47(8): 959-965.

Biswas, A. and Roychoudhury, U.K., 2003.Relative efficacy of some botanicals against sheath blight disease of rice.J. Mycopathol. Res., 41(2): 163-165.

Bonaldo, S. M., Schwan-Estrada, K. R. F., Stangarlin, J. R., Cruz, M. E. S., FioriTutida, A. C. G., 2007. Contribution for the study of antifungal and phytoalexins elicitors in sorghum and soybean activities by eucalyptus (Eucalyptus citriodora). Summa Phytopathologica, 33: 383-387.

Bonaldo, S. M., Schwan-Estrada, K. R. F., Stangarlin, J. R., Tessmann, D. and Scapim, C. A., 2004. Fungitoxicity, phytoalexins elicitor activity and protection of cucumber against Colletotrichum lagenarium, by Eucalyptus citriodora aqueous extract. Fitopatologia Brasileira, 29:128-134.

Bowers, J. H. and Locke, J. C. 2004. Effect of formulated plant extracts and oils on population density of Phytophthora nicotianae in soil and control of Phytophthora blight in the greenhouse. Plant Disease, 88: 11-16.

Burgiel, Z. J. and Smaglowski, M. 2008.Fungistatyczne właściwości olejku z drzewa herbacianego [Fungistatic properties of tea tree oil].Zesz.Probl.Post. Nauk Roln, 529: 13-18.

Burt, S. 2004. Essential oils: their antibacterial properties and potential applications in foods, a review. International Journal of Food Microbiology, 94: 223-253.

Burubai, W. and Eribo, M., 2012. Influence of incubation periods and dosage on the bioefficacy of cow urine against melon aphids (Aphis gossypii) \& pickleworms (Diaphania hyalinata) in watermelon cultivation. Research Journal of Applied Sciences, Engineering and Technology, 4(4): 269-272.

Carré V, Stangarlin, J. R., Becker, A., Zanella, A. L., Gonçalves Júnior, A. C., Schwan-Estrada, K. R. F., Franzener, G. and Cruz, M. E. S., 2006.Postharvest control of Colletotrichum musae in banana (Musa sp.) by camphor (Artemisia camphorata) and chitosan. Scientia Agraria Paranaensis, 5:57-66.

Chuang, P. H., Lee, C. W., Chou, J. Y., Murugan, M., Shieh, B. J. and Chen, H. M. 2007. Antifungal activity of crude extracts and essential oil of Moringa oleifera Lam. Bioresource Technology, 98:232-236.

Colpas, F. T., Schwan-Estrada, K. R. F., Stangarlin, J. R., Ferrarese, M. L., Scapim, C. A., Bonaldo, S. M., 2009. Induction of plant defense responses by Ocimum gratissimum L. (Lamiaceae) leaf extracts. Summa Phytopathologica, 35:191-195.

Cosic, J., Vrandečić, K., Postic, J., Jurković, D. and Ravlić, M. 2010. In vitro antifungal activity of essential oils on growth of phytopathogenic fungi. Poljoprivreda, 16: (2) 25-28.

Cowan, M. M. 1999. Plant products as antimicrobial agents. Clinical Microbiology Reviews, 12: 564-582.

Cowan, M. M. 1999. Plant products as antimicrobial agents. Clinical Microbiology Reviews, 12: 564-582.

Cox, P. A. 1990.Ethnopharmacology and the 
search for new drugs. In: Bioactive compounds from plants. Chadwick D. J. \& Marsh, J. (eds.), John Willey, Chichester, UK, 40-55 pp.

Daayf, F., Schmitt, A. and Bèlanger, R. R. 1995. The effects of plant extracts of Reynoutria sachalinensis on powdery mildew development and leaf physiology of long English cucumber. Plant Disease, 79: $577-$ 580.

Dayan, F. E., Cantrell, C. L. and Duke, S. O. 2009. Natural products in crop protection. Bioorganic and Medicinal Chem., 17 (12): 4022-4034.

Dharam, V. and Sharma R.K., 1985. Efficacy of fungicides XXIX studies on the fungicidal properties of neem.

Dorman, H.J.D. and Deans, S.G., 2000. Antimicrobial agents from plants: Antibacterial activity of plant volatile oils. Journal of Applied Microbiology, 88: 308316. doi:10.1046/j.1365-2672.2000.00969.x

Elsharkawya, M. M. and EL-Sawy, M. M., 2015. Control of Bean common mosaic virus by plant extracts in bean plants. International Journal of Pest Management, DOI: 10.1080/09670874.2014.990947.

Fawzi, E. M., Khalil, A. A. and Afifi, A. F. 2009.Antifungal effect of some plant extracts on Alternaria alternata and Fusarium oxysporum. African Journal of Biotechnology, 8(11): 2590-2597.

Franzener, G., Martinez-Franzener, A. S., Stangarlin, J. R., Furlanetto, C., SchwanEstrada, K. R. F., 2007. Protection of tomato plants by Tagetes patula aqueous extract against Meloidogyne incognita. Nematologia Brasileira, 31:27-36.

Gavaric, N., Mozina, S. S., Kladar, N. and Bozin, B. 2015.Chemical Profile, Antioxidant and Antibacterial Activity of Thyme and Oregano Essential Oils, Thymol and Carvacrol and Their Possible Synergism. Journal of Essential Oil Bearing Plants, 18(4): 1013-1021.

Gnanamanickam, S. S. 2002. Biological control of crop diseases. Marcel Dekker Inc., New York, USA, $468 \mathrm{p}$.

Gohil, V.P. and Vala, D.G.1996.Effect of extracts of some medicinal plants on the growth of Fusarium moniliforme. Indian J. Mycol. Pl.
Pathol., 26(1): 110-111.

Gotora, T. Masaka, L. and Sungirai, M., 2014, Effect of Cow Urine on the Growth Characteristics of Fusarium lateritium, an Important Coffee Fungus in Zimbabwe. International Journal of Agronomy. http://dx.doi.org/10.1155/2014/986068.

Gupta, O.P. 1997. Weed Management: Principles and Practices. Agro. Botanical, Bikarner, pp. $1-10$.

Gurjar, M. S., ALI, S., AKHTAR, M. AND SINGH, K. S. 2012. Efficacy of plant extracts in plant disease management. Agricultural Sciences, 3(3): 425-433.

Gururaja, M.P., Joshi, A.B., Joshi, H., Sathyanarayana, D., Subrahmanyam, E.V.S., Chandrashekar, K.S., 2011. Antidiabetic potential of cow urine in streptozotocininduced diabetic rats. Asian Journal of Traditional Medicines 6(1): 8-13.

Hadian, S. 2012. Antifungal activity of some plant extracts against some plant pathogenic fungi in Iran. Asian Journal of Experimental Biological Sciences, 3(4): 714-718.

Halama, P. and Van Haluwin, C. 2004.Antifungal activity of lichen extracts and lichenic acids. BioControl, 49: 95-107.

Hussain, R., Singh, P. and Kaul, B.L. 2000. Antifungal activities of some aromatic oils against soil and airborne plant pathogens. J. Mycol. Pl. Pathol., 30: 255.

Isman, M. B. and Machial, C. M. 2006, Pesticides based on plant essential oils: from traditional practice to commercialization. In: Naturally occurring bioactive compounds. Rai, M. \& Carpinella, M. C. (eds.). Elsevier, Amsterdam, Netherlands, 29-44 pp.

Jalili-Marandi, R., Hassani, A., Ghosta, Y., Abdollahi, A., Pirzad, A. and Sefidkon, F. 2010. Thymus kotschyanus and Carum copticum essential oils as botanical preservatives for table grape. Journal of Medicinal Plants Research, 4(22): 24242430.

Joy, M., Jacob John, Smitha, K.P. and Nair, R.V. 2004.Inhibitory effects of cashew (Anacardium occidentale L.) on phytopathogenic fungi. Allelopathy J., 13(1): 47-56.

Kamalakannan, A., Shanmugam, V., Surendran, M. and Srinivasan, R., 2001, Antifungal 
properties of plant extracts against Pyricularia grisea, the rice blast pathogen. Indian Phytopath., 54(4): 490-492.

Kandhari, J., 2007, Management of sheath blight of rice through fungicides and botanicals. Indian Phytopathology, 60: 214-217.

Kannan, R. and Subbaraja, K.T. 1999. Comparative evaluation of selected plant extracts and fungicides on the incidence of leaf blight of onion caused by Alternaria alternata Fr. Keissler. Pestology, 23: 5-6.

Kazami, A.R., Niaz, I. and Jilani, G. 1993. Evaluation of some plant extracts for antifungal properties. Pakistan $J$. Phytopathol., 5: 93-97.

Krishna Kishore, G., Pande, S. and Harish, S. 2007. Evaluation of essential oils and their components for broad-spectrum antifungal activity and control of late leaf spot and crown rot diseases in peanut. Plant Disease, 91(4): 375-379.

Krishnamurthi, K., Dutta, D., Sivanesan, S.D, Chakrabarti, T., 2004, Protective effect of distillate and redistillate of cow's urine in human polymorphonuclear leukocytes challenged with established genotoxic chemicals. Biomedical and Environmental Sciences, 17: 247-256.

Kumar, A. and Tripathi, S.C. 1991.Evaluation of the leaf juice of some higher plants for their toxicity against soil borne pathogens. Plant and Soil, 132: 297-301.

Kurucheve, V. and Padmavathi. R. 1998. Management of damping off of chillies with plant products. Indian Phytopath., 51: 228234.

Malik, M.S. 1987. Nematicidal activity of extract of Xanthium strumarium. Pesticides, 21: 1920.

Manoharachary, C. and Gourinath, A., 1988, Effects of plant extracts on four pathogenic fungi.5th International Congress of Plant Pathology, Kyoto.

Marin, S., Velluti, A., Ramos, A. J. and SANCHIS, V., 2004, Effect of essential oils on zearalenone and deoxynivalenol production by Fusarium graminearum in non-sterilized maize grain. Food Microbiology, 21: 313-318.

Masih, H., Peter, J. K. and Tripathi, P. A. 2014.Comparative evaluation of antifungal activity of medicinal plant extracts and chemical fungicides against four plant pathogens. International Journal of Current Microbiology and Applied Sciences, 3(5): 97-109.

Meena, B. and Muthusamy, M. 1999.Integrated management of sheath blight in rice. Vistas of Rice Res., pp. 500-503.

Mermer-Dogu, D. and Zobar D. 2014. Effects of some plant essential oils against Botrytis cinerea and Tetranychus urticae on grapevine. Turkish Journal of Agricultural and Natural Science, Special Issue 1: 12681273.

Mishra, A.K., Dwivedi, S.K. and Kishore, N. (1989) Antifungal activity of some essential oils. National Academy Science Letters, 12: 335-336.

Moezelaar, R., Braam, C., Zomer, J., Gorris, L. G. M. and Smid, E. J. 1999. Volatile plant metabolites for postharvest crop protection. In: Modern Fungicides and Antifungal Compounds II, 1st edn, Lyr, H., Russell, P. E., Dehne, H. W. and Sisler, H. D. (eds.). Intercept Limited, USA, 453- 467 pp.

Montes-Belmont, R. and Carvajal, M., 1998, Control of Aspergillus flavus in maize with plant essential oils and their components. Journal of Food Protection, 61(5): 616-619.

Mueller-Riebau, F., Berger, B. and Yegen, O., 1995, Chemical composition and fungitoxic properties to phytopathogenic fungi of essential oils of selected aromatic plants growing wild in Turkey. Journal of Agricultural and Food Chemistry, 43: 22622266.

Muralidharan, K., Reddy, C.S., Krishnaveni, D. And Laha, G.S., 2003, Evaluation of plantderived commercial products for blast and sheath blight control in rice. Indian Phytopath., 56(2): 151-155.

Murugan, A.M., Shanthi, S., Arunachalam, C., Sivakumar, N., Elamathy, S., Rajapandian, K., 2012., Study on cow urine and Pongamia pinnata Linn seed in farmyard: A natural, cost effective, ecofriendly remedy to bacterial leaf blight (BLB) of paddy. African Journal of Biotechnology, 11(40): 95919598.

Muthamilan, M. and Revathy, N., 2007, Management of tungro virus disease of rice 
with antagonists and botanicals.Journal of Ecobiology, 19: 81-88.

Narayana Bhat, M., Sivaprakasam, K. and Jeyarajan, R. 1990.Symposium on Innovative techniques for the management of crop diseases. Tamil Nadu Agricultural University, Madurai.47 p.

Nashwa, S. M. A. and Abo-Elyousr, K. A. M., 2012, Evaluation of various plant extracts against the early blight disease of tomato plants under greenhouse and field conditions. Plant Protection Science, 48 (2): 74-79.

Nduagu, C., Ekefan, E.J. and Nwankiti, A.O., 2008, Effect of some crude plant extracts on growth of Colletotrichum capsici (Synd) Butler \& Bisby, causal agent of pepper anthracnose. Journal of Applied Biosciences, 6: 184-190.

Numpaque, M. A., Oviedo, L. A., Gil, J. H., García, C. M. and Durango, D. L., 2011, Thymol and carvacrol: biotransformation and antifungal activity against the plant pathogenic fungi Colletotrichum acutatum and Botryodiplodia theobromae. Tropical Plant Pathology, 36(1): 3-13.

Nuzhat, T. and Vidyasagar, G. M., 2013, Antifungal investigations on plant essential oils.A review. International Journal of Pharmacy and Pharmaceutical Sciences, 5(2): 19-28.

Pandey, V.N. and Pant, D.C. 1997.In vitro antifungal activity of some higher plant products against soil-borne phytopathogens. Madras Agric. J., 85: 149-153.

Parveen, S. and Kumar, V.R. 2000. Effect of extracts of some medicinal plants on the growth of Alternaria triticina. J. Phytol. Res., 13: 195-196.

Patil, M.J., Ukey, S.P. and Raut, B.T., 2001. Evaluation of fungicides and botanicals for the management of early blight (Alternaria solani) of tomato. PKV Research Journal, 25: 49-51.

Quarles, W., 1996. EPA exempts least-toxic pesticides. IPM Practice, 18: 16-17.

Rajapandiyan, K., Shanthi, S., Murugan, A.M., Muthu, G.A., Singh, A. J. A. R., 2011.Azadirachta indica - cow urine extract, a novel controlling agent towards clinically significant multidrug resistant Pathogens. Journal of Applied Pharmaceutical Science
1(10): 107-113.

Rakesh, K. N., Dileep, N., Noor Nawaz, A. S., Syed Junaid and Prashith Kekuda, T. R., 2013. Antifungal Activity of Cow Urine against Fungal Pathogens Causing Rhizome Rot of Ginger. Environment \& Ecology 31(3): 1241-1244.

Rakesh, K.N., Dileep, N., Syed Junaidprashith Kekuda, T.R., Vinayaka, K.S. Noor Nawaz, A.S., 2013, Inhibitory Effect of Cow Urine Extracts of Selected Plants against Pathogens Causing Rhizome Rot of Ginger Science, Technology and Arts Research journal, 2(2): 92-96.

Ranjana Sarma, Phookan, A.K. and Bhagabati, K.N. 1999. Efficacy of some plant extracts in the management of sheath blight disease of rice. Indian J. Mycol. Pl. Pathol., 29(3): 336339.

Reddy, C.S., Sudhakar, R., Manoharachary, C., Purohit, D.K., Rama Reddy, S., Singaracharya, M.A. and Girisham, S., 2002. Efficacy of plant products and other chemicals in the management of sheath blight of rice. Frontiers in microbial biotechnology and plant pathology, 263-267.

Rodrigues, E. A., Schwan-Estrada, K. R. F., Stangarlin, J. R., Scapim, C. A., Fiori-Tutida, A. C. F., 2006.Potential of Ocimum gratissimum medicinal plant on Bipolaris sorokiniana control in the wheat seeds. Acta Scientiarum Agronomy, 28: 213-220.

Rodrigues, E., Schwan-Estrada, K. R. F., Fiori, A. C. G., Stangarlin, J. R. and Cruz, M. E. S., 2007. Fungi toxicity, phytoalexins elicitor activity and protection of lettuce in organic growth against Sclerotinia sclerotiorum by ginger extract. Summa Phytopathologica, 33: 20-24.

Romanazzi, G., Lichter, A., Gabler, F. M. and Smilanick, J. L., 2012.Recent advances on the use of natural and safe alternatives to conventional methods to control postharvest gray mold of table grapes. Post-harvest Biology and Technology, 63:141-147.

Satish, S., Mohana, D. C., Raghavendra, M. P. and Raveesha, K. A., 2007.Antifungal activity of some plant extracts against important seed borne pathogens of Aspergillus sp. Journal of Agricultural Technology, 3(1): 109-119. 
Scheuerell, S. and Mahaffee, W., 2002. Compost tea: Principles and prospects for plant disease control. Compost Science \& Utilization, 10: 313-338.

Shin, M. H., Kim, J. H., Choi, H. W., Keum, Y. S. and Chun, S. C. 2014.Effect of Thymol and Linalool fumigation on postharvest diseases of table grapes. Mycobiology, 42(3): 262268.

Shivapuri, A., Sharma, O.P. and Jhamaria, S.L. 1997. Fungitoxic properties of plant extracts against pathogenic fungi. J. Mycol. Pl. Pathol., 27(1): 29-31.

Sindhan, G.S., Indra Hooda and Prashar, R.D. 1999. Evaluation of plant extracts for the control of powdery mildew of pea. J. Mycol. Pl. Pathol., 29: 257-258.

Singh, S.K., Singh, U.P. and Leepika Tuli. 2001. Effect of some plant extracts on Alternaria tenuissima (Kunze Expers.), the causal agent of leaf blight of pigeon pea (Cajanus cajan L.). Indian J. Plant Pathol., 19: 29-33.

Sokmen, A., Vardar-Unlu, G., Darici, N. and SAHIN, S., 2000. Antimicrobial activities of methanolic extracts of various plants growing in the Sivas district. J. Infection, 14: 253-256.

Srinivas, T., Rao, M.S., Reddy, P.S. and Reddy, P.N., 1997.Integrated management of leaf spot of groundnut (Arachis hypogaea L.) with botanicals and chemicals. Zeitschrift fur Pflanzenkrankheiten und Pflanzenschutz, 104: 528-530.

Srivastava, A., Srivastava, S. and Verma, H. N., 2006. Induction of antiviral resistance in Carica papaya by systemic resistance inducing protein from Clerodendrum aculeatum. Abstract In: XVI Ann. convention of IVS and Int. symp. management of vector-borne viruses, ICRISAT, Patancheru, Hyderabad, India.

Stangarlin, J. R. and Pascholati, S. F., 1994.Protection of maize seedlings against Exserohilum turcicum by Saccharomyces cerevisiae. Summa Phytopathologica, 20:1621.

Sumathi, J., 1996.Management of major disease of tomato (Lycopersicon esculentum Mill.) using antiviral and antifungal principles. M.Sc. (Ag.) Thesis, Tamil Nadu Agricultural University, Coimbatore, $162 \mathrm{p}$.
Sunder, S., Singh, R. and Dodan, D.S., 2005.Management of bacterial blight of rice with botanical extracts and non-conventional chemicals. Plant Disease Research, 20: 1217.

Sundriyal, R.C. 1991. Fungitoxic properties of flower extracts of some wild plants of Garhwal Himalayas. Adv. Plant Sci., 4: 230234.

Surwase, A.G., Badgire, D.R. and Suryawanshi, A.P. 2009.Management of pea powdery mildew by fungicides, botanicals and bioagents. Annals of Plant Protection Sciences, 17: 384-388.

Tewari, S.N. and Mandakini Nayak, 1991. Activity of four plant leaf extracts against three fungal pathogens of rice. Trop. Agric., 68(4): 373-375.

Tewari, S.N., 1995.Ocimum sanctum L., A botanical fungicide for rice blast control. Trop. Sci., 35: 263-273.

Tiwari, R.K.S. and Das, K., 2011. Inhibitory effect of cow urine based plant extracts against Rhizoctonia solani causing sheath blight of rice. Indian Phytopathology, 64(3): 265-268.

Tsao, R. and Zhou, T. 2000. Antifungal activity of monoterpenoids against postharvest pathogens Botrytis cinerea and Monilinia fructicola. Journal of Essential Oil Research, 12: 113-121.

Upadhyaya, M.R. and Gupta, R.C. 1990. Effect of extracts of some medicinal plants on the growth of Curvularia lunata. Indian Journal of Mycology and Plant Pathology, 20: 144145.

Upperi, S. N., Lokesh, B. K., Maraddi, G. N and Agnal, M. B., 2009. Jeevamrutha, a new organic approach for disease management and crop production in pomegranate and groundnut. Environment and Ecology, 27: 202-204.

Ushiki, J., Hayakawa, Y. and Tadano, T., 1996. Medicinal plants for suppressing soil borne plant diseases. Screening for medicinal plants with antimicrobial activity in roots. Soil Sci. Pl. Nutr., 42: 423-426.

Vasant P. Pawar and Ashok Chavan M., 2010. Incidence of Powdery Mildew on Cucurbit Plants and its Ecofriendly Management. Journal of Ecobiotechnology, 2(6): 29-43. 
Vijayan, M., 1989. Studies on early blight of tomato caused by Alternaria solani (EII. and Mart.)Jones and Grout. M.Sc. (Ag.) Thesis, Tamil Nadu Agricultural University, Coimbatore, India, 106p.

Villanueva Bermejo, D., Angelov, I., Vicente, G., Stateva, R. P., Rodriguez Garcíarisco, M., Reglero, G., Ibañez, E. and Fornari, T. 2015. Extraction of thymol from different varieties of thyme plants using green solvents. Journal of the Science of Food and Agriculture, 95(14):2901-2907.

Wang, W., Ben-Daniel, B. H. and Cohen, Y. 2004. Control of plant diseases by extracts of Inula viscosa. Phytopathology, 94: 10421047.

Yadav, H., Yadav, M., Jain, S., Bhardwaj, A., Singh, V., Prakash, O., Marotta, F., 2008. Antimicrobial property of a herbal preparation containing Dalbergia sissoo and Datura tramonium with cow urine against pathogenic bacteria. International Journal of Immunopathology and Pharmacology, 21(4): 1013-1020.
Yashoda Kambar, Vivek, M. N., Manasa, M., Prashith Kekuda, T. R. and Noor Nawaz, A. S., 2013. Inhibitory Effect of Cow Urine against Colletotrichum capsici isolated from Anthracnose of Chilli (Capsicum annuum L.). Sci. Technol. Arts Res. J., 2(4): 91-93.

Yegen, O., Begger, B. and Heitefuss, R., 1992. Studies on the fungitoxic effect for extracts of six selected plants from Turkey on phytopathogenic fungi. Zeitschrift fur Pflanzenkrankheiten und Pflanzenschütz, 99: 349-359.

Zaker, M. and Mosallanejad, H., 2010. Antifungal activity of some plant extracts on Alternaria alternata, the causal agent of alternaria leaf spot of potato. Pakistan Journal of Biological Sciences, 13(21): 1023-1029.

Zaker, M., 2014. Antifungal evaluation of some plant extracts in controlling Fusarium solani, the causal agent of potato dry rot in vitro and in vivo. International Journal of Agriculture and Biosciences, 3(4): 190- 195.

\section{How to cite this article:}

Gowdra Nagamma, G. Vijayalakshmi, M.T. Sanjay, C.R. Jahir Basha, N. Mallikarjuna and Mahin Sharif. 2019. A Review on Eco-Friendly Natural Plant and Animal Products for Plant Diseases Management. Int.J.Curr.Microbiol.App.Sci. 8(08): 1957-1977. doi: https://doi.org/10.20546/ijcmas.2019.808.230 